\title{
Rare Earth Element and Incompatible Trace Element Abundances in Emeralds Reveal Their Formation Environments
}

\author{
Raquel Alonso-Perez ${ }^{1, *(D)}$ and James M. D. Day ${ }^{2}$ (D) \\ 1 Department of Earth and Planetary Sciences, Harvard University, Cambridge, MA 02138, USA \\ 2 Scripps Institution of Oceanography, University of California San Diego, La Jolla, CA 92093, USA; \\ jmdday@ucsd.edu \\ * Correspondence: ralonso@fas.harvard.edu; Tel.: +1-617-301-2175
}

Citation: Alonso-Perez, R.; Day, J.M.D. Rare Earth Element and Incompatible Trace Element Abundances in Emeralds Reveal Their Formation Environments. Minerals 2021, 11, 513. https:// doi.org/10.3390/min11050513

Academic Editors: Paul Sylvester, Alexander R. Cruden, Sytle M. Antao, Huifang $\mathrm{Xu}$, Nigel J. Cook, Theodore J. Bornhorst, Hanumantha Rao Kota and Anna H. Kaksonen

Received: 29 April 2021

Accepted: 11 May 2021

Published: 13 May 2021

Publisher's Note: MDPI stays neutral with regard to jurisdictional claims in published maps and institutional affiliations.

Copyright: (c) 2021 by the authors. Licensee MDPI, Basel, Switzerland. This article is an open access article distributed under the terms and conditions of the Creative Commons Attribution (CC BY) license (https:/ / creativecommons.org/licenses/by/ $4.0 /)$.

\begin{abstract}
Emeralds require the unusual association of typically compatible elements $(\mathrm{Cr}, \mathrm{V})$, with incompatible Be to form, and occur in complex tectonic settings associated with sediments (type IIB; Colombia) or, more commonly, with magmatism and regional metamorphism (IA). Precise rare earth element (REE) and incompatible trace element abundances are reported for a global suite of emeralds, enabling the identification of the environments in which they formed. Type IIB emeralds have nearly flat continental crust normalized REE patterns $\left(\mathrm{La} / \mathrm{Yb}_{\mathrm{CC}}=\sim 2\right)$, consistent with a sedimentary source origin. Type IA emerald REE patterns have upturns in the heavy REE ( $\mathrm{La} / \mathrm{Yb}_{\mathrm{CC}}=\sim 0.3$ ), a feature also shared with South African emeralds occurring in Archaean host rocks. Modeling of type IA emerald compositions indicates that they form from magmatic fluids of sedimentary (S)-type granite melts interacting with $\mathrm{Cr}$, V-rich mafic-ultramafic crustal protoliths. This geochemical signature links emerald formation with continental suture zones. Diamonds, rubies, and sapphires have been considered as 'plate tectonic gemstones' based on mineral inclusions within them, or associations with plate tectonic indicators. Emeralds are distinct plate tectonic gemstones, recording geochemical evidence for origin within their mineral structure, and indicating that plate tectonic processes have led to emerald deposit formation since at least the Archaean.
\end{abstract}

Keywords: emeralds; gemstones; trace elements; rare earth elements; plate tectonics; sediments; s-type granite

\section{Introduction}

Emeralds are a green variety of beryl $\left(\mathrm{Be}_{3} \mathrm{Al}_{2} \mathrm{Si}_{6} \mathrm{O}_{18}\right)$ and have been prized gems since antiquity [1]. Beryl is a cyclosilicate composed of hexagonal rings $\left(\mathrm{Si}_{6} \mathrm{O}_{18}\right)$ connected by Be atoms on tetrahedral sites, and $\mathrm{Al}$ atoms on octahedral sites [1]. It is substitution on the octahedral site, primarily by $\mathrm{Cr}$ and/or $\mathrm{V}$, that is responsible for the vivid green color of emerald [2]. Emeralds are scarce commodities requiring the interaction of fluids from aluminous quartzo-feldspathic Be-rich sources with $\mathrm{Cr}$-V-Fe-rich mafic-ultramafic igneous/metamorphic (tectonic-magmatic-metamorphic-related), or Cr-V-rich sedimentary crustal protoliths. Despite the limiting formation requirements, there are nearly fifty recognized emerald deposits globally, occurring across North and South America, Europe, Asia, Africa and Australasia, and they range in inferred formation age from the Archaean ( 3 Ga) to the Cenozoic ( 9 Ma) (Figure 1) [1,3].

Deposits containing emeralds are typically described individually in the literature and emphasize significant complexity in the geological setting (e.g., [4-11] and Supplementary Information (SI) for a detail list of bibliography). Attempts to classify emeralds in a coherent manner, and to enable use of this mineral variety more widely to understand geological processes have linked their formation to broadly magmatic (tectonic-magmaticrelated), metamorphic (tectonic-metamorphic-related), and sedimentary processes [10] (Figure 1). These studies have demonstrated variability in the major element chemical characteristics of emeralds, especially V, Cr and Fe contents, with limited quantitative data 
available for trace element abundances $[10,12,13]$. While some emerald deposits are hosted in sedimentary rocks (including Colombian emeralds, Type IIB) or granitoids (types IB, IC, IIC), the preponderance ( $80 \%$ ) of worldwide emerald deposits are related to magmatically derived granitic fluids that have interacted with mafic-ultramafic host rocks (types IA, IID).

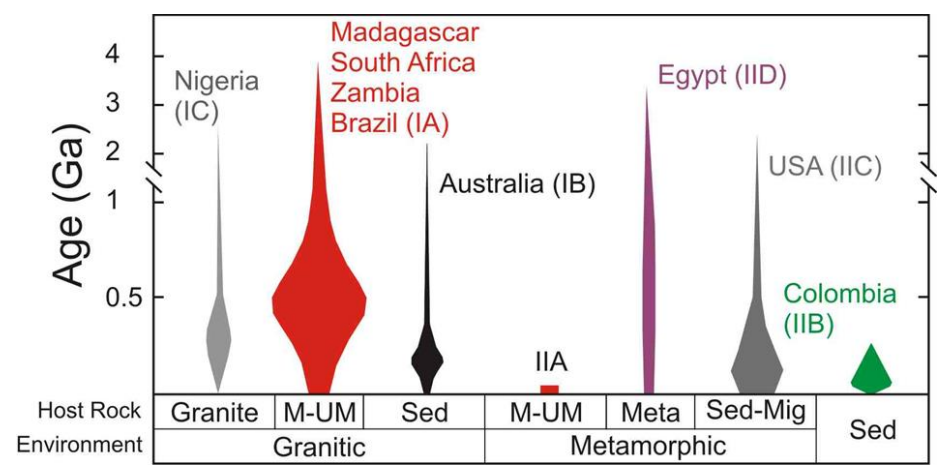

Figure 1. Summary of total age distribution of emerald host rock deposits classified by type. Type classifications (e.g., IC, IA, IB, IIA, IID, IIC and IIB) are based on host rock (abbreviations: M-UM = mafic-ultramafic; Sed = sedimentary; Meta = metamorphic; Sed-Mig = sedimentary-migmatite) and environment of formation [10]. Compilation of ages are in Table 1 and Table S4; relative distribution is shown (wider regions of indicator bars indicate a larger population of deposits of that age, and times can be discontinuous).

The most refined model for emerald genesis comes from studies of Colombian sediment-hosted deposits, which although tectonically and temporally distinct [14], were formed by the interaction of evaporitic brines and black shale $[15,16]$. The thermal reduction of sulphate, at $300-330{ }^{\circ} \mathrm{C}$ by brine, in the presence of organic matter in the black shale led to albitization, the formation of pyrite $\left(\mathrm{FeS}_{2}\right)$, and Be-bearing mineralization with the formation of virtually Fe-free, V and Cr-rich emeralds. Despite their sedimentary origin, the Colombian emerald deposits are ultimately related to subduction and orogeny, with the formation of a sedimentary back-arc basin and the sourcing of sediments from the Jurassic to Cretaceous Andean arc [17]. In contrast, most of the world's emeralds are related to magmatically derived fluids that have interacted with mafic-ultramafic host rocks (types IA, IID, [10], and formation models for these types of emerald are generally related to individual deposits. For example, whether there is a link as to how magmatic, metamorphic and sedimentary-hosted emeralds are formed is, hitherto, unknown.

To examine the formation of emeralds, we present the first comprehensive trace element abundance analyses of inclusion-free emeralds from ten representative global locations spanning 13 different economically viable deposits, covering the major classification types of emerald [10] (Figure 1). Unlike previous studies using microbeam techniques $[12,13,18]$, we present solution trace element abundance analyses from the dissolution of significant quantities of emerald $(>10 \mathrm{mg})$. This method has the advantage of enabling the precise analysis of concentrations of trace elements in emerald. In particular, the method enables the highest precision REE abundances to be determined for emeralds. To examine this method in context with previous work, we compare the data obtained for type IA Malagasy emeralds with a microbeam technique (laser ablation inductively coupled plasma mass spectrometry) and with the host rock bulk compositions, to evaluate where the incompatible trace elements are sited in emeralds, and how country rock composition might affect emerald composition. For comprehensiveness, we also present analyses for other beryl varieties (red beryl, aquamarine, heliodor), synthetic flux-grown emeralds, as well as individual mineral inclusions within emeralds and beryls and mixtures of the mineral and their inclusions. In so doing, it is the intention of this work to provide an overall view of emerald trace element chemistry in context with those of other beryls, rather than to focus on provenance or mineral chemistry, as has traditionally been the case with microbeam studies of trace elements in emeralds. 
Table 1. Geological information for emeralds examined in this study.

\begin{tabular}{|c|c|c|c|c|c|c|c|c|c|}
\hline Region & Class & Samples Number & Locality & Geology & $\begin{array}{l}\text { Metamorphic } \\
\text { Facies }\end{array}$ & Temp. ${ }^{\circ} \mathrm{C}$ & P, bar & Age Ma & Age/Method \\
\hline Brazil & IA & L2017.27.5 & $\begin{array}{l}\text { Bonfim farm, Caiçara } \\
\text { do Rio do Vento, } \\
\text { Borborema mineral } \\
\text { province, Rio Grande } \\
\text { do Norte }\end{array}$ & $\begin{array}{l}\text { Pegmatitic bodies hosted by } \\
\text { amphibolites in a succession of talc, } \\
\text { talc-amphibole, and biotite } \pm \\
\text { amphibole schists and within a } \\
\text { shear zone. }\end{array}$ & $\begin{array}{l}\text { Greenschist to } \\
\text { low-amphibolite }\end{array}$ & $330-470$ & $200-600$ & 553 & $\begin{array}{l}\text { Blackwall zone, } \\
\text { mica }{ }^{40} \mathrm{Ar} /{ }^{39} \mathrm{Ar} \\
\text { method }\end{array}$ \\
\hline Madagascar & IA & $\begin{array}{c}2017-14.1,2017-14.2 \\
2017-14.3\end{array}$ & $\begin{array}{l}\text { Ankadilalana emerald } \\
\text { mine, Ambalahosy } \\
\text { Nord Commune, } \\
\text { Mananjary District, } \\
\text { Vatovavy Fitovinany }\end{array}$ & $\begin{array}{l}\text { Black-wall reaction zones } \\
\text { (amphibolite-phlogopite-rich rocks } \\
\text { occasionally pillowed) between } \\
\text { migmatitic gneiss, talc-schist and } \\
\text { lenses of chromite-bearing } \\
\text { serpentinites within a shear zone }\end{array}$ & Amphibolite & $250-500$ & $150-200$ & 490 & $\begin{array}{l}\text { Phlogopite, } \\
{ }^{40} \mathrm{Ar} /{ }^{39} \mathrm{Ar} \\
\text { method }\end{array}$ \\
\hline Madagascar & IA & $\begin{array}{c}\text { 2017.9.3-1, } \\
\text { 2017.9.3-2, } \\
2017.9 .3-3,2017.9 .4\end{array}$ & $\begin{array}{l}\text { Irondro mine, } \\
\text { Andonabe Commune, } \\
\text { Mananjary District, } \\
\text { Vatovavy Fitovinany }\end{array}$ & $\begin{array}{l}\text { Black-wall reaction zones } \\
\text { (amphibolite-phlogopite-rich rocks } \\
\text { occasionally pillowed) between } \\
\text { migmatitic gneiss, talc-schist and } \\
\text { lenses of chromite-bearing } \\
\text { serpentinites within a shear zone }\end{array}$ & Amphibolite & $250-500$ & $150-200$ & 490 & $\begin{array}{l}\text { Phlogopite, } \\
{ }^{40} \mathrm{Ar} /{ }^{39} \mathrm{Ar} \\
\text { method }\end{array}$ \\
\hline South Africa & IA & $\begin{array}{c}\text { 2017.5.2, RSA1, } \\
\text { RSA2, RSA3, RSA4 }\end{array}$ & $\begin{array}{l}\text { Gravelotte Emerald } \\
\text { Mine, Gravelotte, } \\
\text { Murchison Range, } \\
\text { Limpopo Province }\end{array}$ & $\begin{array}{l}\text { Black-wall zones associated with } \\
\text { ultramafic rocks; Archean tonalitic } \\
\text { gneisses with talc-chlorite, actinolite, } \\
\text { and biotite schist, interpreted as a } \\
\text { tectonic mélange }\end{array}$ & Green-schist & $450-500$ & 400 & 2.97 & $\begin{array}{l}\text { Granitoid zircon, } \\
\text { U-Pb method }\end{array}$ \\
\hline Zambia & IA & $\begin{array}{c}\text { 2015.6, 2015.6.1, } \\
2015.6 .4,2015.6 .5\end{array}$ & $\begin{array}{l}\text { Kagem Emerald Mine, } \\
\text { Kafubu Emerald } \\
\text { District, Lufwanyama, } \\
\text { Copperbelt }\end{array}$ & $\begin{array}{l}\text { Talc-chlorite } \pm \text { actinolite } \pm \\
\text { magnetite metabasites identified as } \\
\text { metamorphosed komatiites and } \\
\text { metasomatized by Be-bearing fluids } \\
\text { derived from hydrothermal veins }\end{array}$ & Amphibolite & $360-390$ & $400-450$ & $452-447$ & $\begin{array}{l}\text { Muscovite, } \\
{ }^{40} \mathrm{Ar} /{ }^{39} \mathrm{Ar} \\
\text { method }\end{array}$ \\
\hline Australia & IB & 2016.6.13 & $\begin{array}{l}\text { New South Wales, } \\
\text { Clive Co.,Torrington }\end{array}$ & $\begin{array}{l}\text { At the contact between I-Type } \\
\text { granite and sediments-pegmatite } \\
\text { and aplite into mudstone } \\
\text { and silstone }\end{array}$ & $\begin{array}{l}\text { Amphibolite to } \\
\text { Green-schist }\end{array}$ & $350-400$ & $150-250$ & $298-236$ & $\begin{array}{l}\mathrm{Rb} / \mathrm{Sr} \text { whole } \\
\text { rock method }\end{array}$ \\
\hline
\end{tabular}


Table 1. Cont.

\begin{tabular}{|c|c|c|c|c|c|c|c|c|c|}
\hline Region & Class & Samples Number & Locality & Geology & $\begin{array}{l}\text { Metamorphic } \\
\text { Facies }\end{array}$ & Temp. ${ }^{\circ} \mathrm{C}$ & P, bar & Age Ma & Age/Method \\
\hline Nigeria & IC & L2017.27.4 & Jos Plateau, Plateau & $\begin{array}{l}\text { Miarolitic cavities subjected to } \\
\text { autometasomatic alteration }\end{array}$ & Amphibolite & $400-450$ & $200-300$ & $\begin{array}{l}600-450 \\
190-144\end{array}$ & $\begin{array}{c}\text { Regional } \\
\text { terranes }\end{array}$ \\
\hline Austria & IIA & 2016.6.16 & $\begin{array}{l}\text { Emerald deposit, } \\
\text { Leckbachgraben, } \\
\text { Nasenkopf, Habach } \\
\text { Valley, Hohe Tauern, } \\
\text { Salzburg }\end{array}$ & $\begin{array}{l}\text { Emerald-bearing biotite-chlorite } \\
\text { schists, intercalated between } \\
\text { scheelite-bearing banded gneisses } \\
\text { and amphibolites }\end{array}$ & Green-schist & 700 & 5000 & $31-21$ & $\begin{array}{c}\text { U-Pb apatite } \\
\text { method }\end{array}$ \\
\hline Colombia & IIB & $\begin{array}{c}88296,92642,97472 \\
125052,129266 \\
138646,138646.1 \\
138646.2,138646.3 \\
138646.7,138646.8\end{array}$ & $\begin{array}{l}\text { Muzo Mine, } \\
\text { Mun. de Muzo, } \\
\text { Vasquez-Yacopí } \\
\text { mining district, } \\
\text { Boyacá Department }\end{array}$ & $\begin{array}{l}\text { Emerald hosted in a sedimentary } \\
\text { basin of sandstone, limestone, black } \\
\text { shale and evaporites and formed by } \\
\text { hydrothermal brines and sulfate } \\
\text { reduction in combination with } \\
\text { organic-rich black shales }\end{array}$ & $\begin{array}{l}\text { Low grade } \\
\text { metamorphism }\end{array}$ & $290-360$ & 100 & $35-38$ & $\begin{array}{l}\text { Muscovite, } \\
{ }^{40} \mathrm{Ar} /{ }^{39} \mathrm{Ar} \\
\text { method }\end{array}$ \\
\hline Colombia & IIB & $97019,2016.6 .5$ & $\begin{array}{l}\text { Mun. de Chivor, } \\
\text { Guavió-Guatéque } \\
\text { mining district, } \\
\text { Boyacá Department }\end{array}$ & $\begin{array}{l}\text { Emerald hosted in a sedimentary } \\
\text { basin of sandstone, limestone, black } \\
\text { shale and evaporites and formed by } \\
\text { hydrothermal brines and sulfate } \\
\text { reduction in combination with } \\
\text { organic-rich black shales }\end{array}$ & $\begin{array}{l}\text { Low grade } \\
\text { metamorphism }\end{array}$ & $290-360$ & 100 & 61 & $\begin{array}{l}\text { Muscovite, } \\
{ }^{40} \mathrm{Ar} /{ }^{3} 9 \mathrm{Ar} \\
\text { method }\end{array}$ \\
\hline USA & IIC & 124888 & $\begin{array}{l}\text { Rist Mine, Hiddenite, } \\
\text { Alexander Co., } \\
\text { North Carolina }\end{array}$ & $\begin{array}{l}\text { Emerald hosted in precambrian } \\
\text { migmatitic schists and gneisses } \\
\text { intruded by the medium-grained } \\
\text { leucocratics. The emerald formation } \\
\text { has been related to pegmatitic fluids } \\
\text { as hydrothermal Alpine-type veins } \\
\text { instead of pegmatites }\end{array}$ & Amphibolite & $230-290$ & $\begin{array}{c}\text { low } \\
\text { pressure }\end{array}$ & $500-750$ & $\begin{array}{l}\text { Regional } \\
\text { terranes }\end{array}$ \\
\hline
\end{tabular}


Table 1. Cont.

\begin{tabular}{|c|c|c|c|c|c|c|c|c|c|}
\hline Region & Class & Samples Number & Locality & Geology & $\begin{array}{l}\text { Metamorphic } \\
\text { Facies }\end{array}$ & Temp. ${ }^{\circ} \mathrm{C}$ & P, bar & Age Ma & Age/Method \\
\hline Egypt & IID & 2016.6 .3 & $\begin{array}{c}\text { Wadi, Sikait-Zabara } \\
\text { region, Eastern } \\
\text { Desert, Read Sea }\end{array}$ & $\begin{array}{c}\text { Volcano-sedimentary sequence } \\
\text { featuring an ophiolitic tectonic } \\
\text { melange composed of } \\
\text { metamorphosed } \\
\text { M-UMR overlying biotite } \\
\text { orthogneiss. Syntectonic intrusions } \\
\text { of leucogranites and pegmatites } \\
\text { occurred } \\
\text { along the ductile shear-zone }\end{array}$ & $\begin{array}{l}\text { Greenschist- } \\
\text { amphibolite }\end{array}$ & $485-571$ & $680-770$ & 595 & $\begin{array}{l}\text { Muscovite, } \\
{ }^{40} \mathrm{Ar} /{ }^{39} \mathrm{Ar} \\
\text { method }\end{array}$ \\
\hline Egypt & IID & 2018.13 .2 & $\begin{array}{c}\text { Gebel Zabara, } \\
\text { Sikait-Zabara region, } \\
\text { Eastern Desert, } \\
\text { Read Sea }\end{array}$ & $\begin{array}{c}\text { Volcano-sedimentary sequence } \\
\text { featuring an ophiolitic tectonic } \\
\text { melange composed of } \\
\text { metamorphosed } \\
\text { M-UMR overlying biotite } \\
\text { orthogneiss. Syntectonic intrusions } \\
\text { of leucogranites and pegmatites } \\
\text { occurred } \\
\text { along the ductile shear-zone }\end{array}$ & $\begin{array}{l}\text { Greenschist- } \\
\text { amphibolite }\end{array}$ & $485-571$ & $680-770$ & 595 & $\begin{array}{c}\text { Muscovite, } \\
{ }^{40} \mathrm{Ar} /{ }^{39} \mathrm{Ar} \\
\text { method }\end{array}$ \\
\hline
\end{tabular}




\section{Materials and Methods}

Gem-quality emeralds from the gem and mineral collection at the Mineralogical and Geological Museum, Harvard University (MGMH), were analyzed in this study. Samples included emeralds within the original matrix, loose emerald crystals and cut gemstones from known deposits. Country, classification type [10], sample number, locality with details regarding main deposits and individual mines, general geology, metamorphic facies, temperature, pressure, age, and method of age determination are summarized in Table 1. The compilation of world emerald deposits, age, environment of formation and references to previous studies are presented in the SI, Tables S4 and S5. Temperatures and pressures estimated from fluid inclusions, and ages either by a dating method and/or metamorphic studies are presented without prejudice.

A total of six different beryl varieties (non-emerald from the MGMH collection) were also analyzed to examine how they might vary in terms of their trace element abundances (SI, Table S3). Since no high-precision data are available for these mineral varieties, this task is particularly important for examining how unique emerald trace element compositions might be. Aquamarine (blue beryl variety): MGMH\#140910—Erongo Mountain, Karibib, Erongo Region, Namibia; MGMH\#4437_Skardu, Skardu District, Gilgit-Baltistan, Pakistan; Red beryl: MGMH\#118253—Ruby Violet claims, Red Emerald Mine, Beaver Co., UT, USA; Heliodor (yellow beryl variety): MGMH\#114903-Brazil; MGMH\#139573_VolodarskVolynskii, Zhytomyr Oblast, Ukraine. Unlike emeralds, the chromophores for these beryls are $\mathrm{Fe}, \mathrm{Mn}$ and probably $\mathrm{Co}$, occurring at different oxidation states. For aquamarine, charge transfer between $\mathrm{Fe}^{2+}$ and $\mathrm{Fe}^{3+}$ has been attributed as the cause of color [19], and the higher the $\mathrm{FeO}$ content, the darker blue the aquamarines are likely to become [20]. Red beryl is colored by traces of $\mathrm{Mn}^{2+}$ [21], while the color of heliodor is due to interaction between $\mathrm{Fe}^{3+}$ and its oxygens [19]. Aquamarine crystals from the Erongo region are formed in miarolitic cavities of highly evolved and enriched pegmatites in beryllium and boron [22]; aquamarine from the Gilgit area in Pakistan are hosted in pegmatite veins [23], and in the presence of other minerals, as is the case for heliodor from Brazil and Ukraine. The red beryl is hosted in rhyolites and formed by hydrothermal processes at low pressure [21].

A single Gilson synthetic emerald (MGMH\#109678, SI Table S3) was also examined in this study, for comparative purposes. Early work to grow emeralds by the flux method by Gilson, consisted of heating powdered natural emerald in a boric acid flux $\left(\mathrm{Li}_{2} \mathrm{O}_{3}-\mathrm{MoO}_{3}\right)$, resulting in emerald prisms [24].

Due to the known presence of impurities in emeralds and other beryl minerals, both crystals 'pure' and free from visible inclusions, as well as crystals with visible inclusion were examined (SI, Table S3). To be clear, these samples represent mixed compositions, and the quality of the measurement of the solutions made from them is equal to that for the pure emerald samples. They are important for ascertaining and distinguishing highpurity emerald analyses and are useful for comparative purposes. During preparation for solution trace element analysis, these grains were included, even if inclusions were visible, to obtain a representative sample set, and to investigate the role of inclusions in emerald geochemistry. On the other hand, since many emerald crystals can be zoned, fragments with visible zoning were excluded from study. Important in this comparison is that an advantage of micro-beam techniques is that these inclusions can normally be avoided. On the other hand, micro-beam techniques do not always allow quantification of all concentrations of rare earth elements (REE) at sufficient precision, making the assessment of the REE patterns less definitive [25].

Analytical procedures were undertaken at the Scripps Isotope Geochemistry Laboratory (SIGL) (La Jolla, CA, USA) with modification to standard methods for solution trace-element abundance analyses [26]. Around $10 \mathrm{mg}$ of emerald, other beryls and synthetic emerald, $\sim 2-10 \mathrm{mg}$ inclusions, or $50 \mathrm{mg}$ of material from a $100 \mathrm{~g}$ homogeneous finely powdered rock sample were separately digested in Teflon beakers using Teflon-distilled concentrated Optima-grade $\mathrm{HF}(4 \mathrm{~mL})$ and triple Teflon-distilled $\mathrm{HNO}_{3}(1 \mathrm{~mL})$ for $>72 \mathrm{~h}$ on a hotplate at $150{ }^{\circ} \mathrm{C}$, along with total procedural blanks, emerald internal standards, 
and terrestrial peridotite, basalt and andesite standards (BHVO-2, BCR-2, BIR-1a, AGV-2, HARZ-01) used for calibration curves, or as unknowns. After cooling, the solutions were dried down under class 10 air flow and equilibrated three times in Teflon-distilled concentrated $\mathrm{HNO}_{3}(1 \mathrm{~mL})$, by repeated dissolution and drying, to breakdown residual fluorides. After these steps, clear 'stock' solutions were obtained. From the stock solutions, elemental abundances were determined from $500 \times($ REE), $5000 \times$ (remaining trace elements, minor elements), 50,000 $\times$ (major elements) dilutions. Beryllium concentrations were determined using external Be calibration solutions.

Analyses were performed using a ThermoScientific iCAP Qc quadrupole inductively coupled plasma mass spectrometer (ICP-MS, Thermo Fisher Scientific Inc., Waltham, MA, USA). Reported data are blank-corrected and blanks were systematically $<0.1 \%$ of the analyte determination. Due to HF desilicification, $\mathrm{Si}$ was determined by difference. For the quantitatively determined major-elements, accuracy is typically better than $5 \%$ on most major elements, determined from cross-calibration by X-ray fluorescence and ICPMS of rock samples spanning 7 to $47 \mathrm{wt} . \% \mathrm{MgO}$ [27]. Two analytical campaigns were performed (denoted as a and b, in SI, Tables S1-S3), separated by approximately six months, and the long-term reproducibility of trace- and minor-element abundance data from these campaigns was better than $4 \%$ for most elements (Figure 6 and SI, Table S2). There is no difference, outside of uncertainties, between long-term standard reproducibility between the two campaigns based on analyses of BHVO-2, BIR-1, or BCR-2 standard reference materials.

To determine whether solution trace element analyses faithfully reflect the composition of emeralds, and are not dominated by fluid or solid inclusions, trace elements for some Malagasy emeralds were measured using a New Wave UP-213nm laser ablation system (New Wave Research, Fremont, CA, USA) coupled to a ThermoScientific iCAPq inductively coupled plasma mass spectrometer (LA-ICP-MS) at the SIGL (Figure 6). Glass standards NIST 610, NIST 612, BHVO-2g, BCR-2g, and BIR-1g were used for standardization with reproducibility generally better than $10 \%$. Rasters were carried out with a laser beam diameter or $100 \mu \mathrm{m}$ with a laser repetition rate of $5 \mathrm{~Hz}$ at $\sim 3.5 \mathrm{~J} \cdot \mathrm{cm}^{-2}$. Each analysis consisted of $60 \mathrm{~s}$ of data collection, comprising a $\sim 20 \mathrm{~s}$ background and $\sim 40 \mathrm{~s}$ of laser ablation. Each analysis was normalized to iron content and data are reported in the Supplementary Information Table S3. The majority of large ion lithophile elements, high field strength elements and some of the HREE were above the limits of quantification, although many of the REE were below this threshold, resulting in incomplete trace element abundance profiles for samples measured by LA-ICP-MS. After LA-ICP-MS, surfaces of samples were examined using a ThermoScientific Phenom XL Scanning Electron Microscope (Thermo Fisher Scientific Inc.) to examine evidence for microscopic inclusions. While solid inclusions were observed, such as a $\sim 10 \mu \mathrm{m}$ sylvite grain in a Malagasy emerald, the surfaces and interiors of the emeralds examined were relatively homogeneous (Figure 2). 

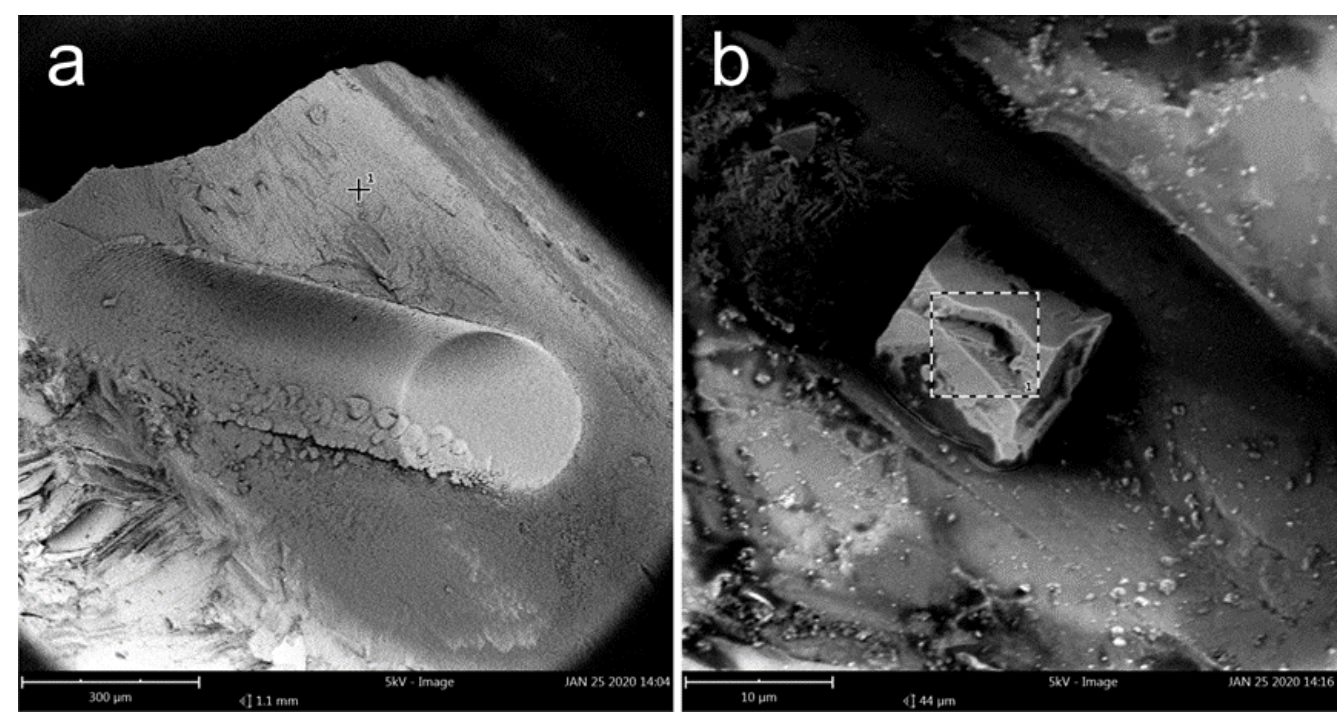

Figure 2. Back-scatter electron images of emeralds from Madagascar. (a) Surface of a Malagasy emerald with a $100 \mu \mathrm{m}$ raster pit. Note textural variations on the surface of the emerald; EDS mapping suggests broad homogeneity across the shown image; (b) solid inclusions occur in emeralds, along with fluid inclusions. For example, this sylvite grain within a fracture in a Malagasy emerald.

\section{Results}

The first comprehensive solution trace element abundance dataset for emeralds, spanning all major deposit type: type IA (Brazil, Madagascar, South Africa, Zambia), IB (Australia), IC (Nigeria), IIA (Austria), IIB (Colombia), IIC (United States of America) and IID (Egypt), combined with ancillary data for inclusions, impure emeralds and other beryl types are reported in SI, Tables S1 and S3.

\subsection{Major Element Composition of Emeralds}

In order to classify the studied emeralds and to filter for potential fluid inclusion compositions, major elements were determined during solution ICP-MS analyses. The oxide abundances were converted to atoms per formula unit (APFU), to examine appropriate stoichiometry (idealized as $\mathrm{Be}_{3} \mathrm{Al}_{2} \mathrm{Si}_{6} \mathrm{O}_{18}$ ). While the pure emeralds major element data are good approximations of compositions, these analyses are likely to be less accurate than electron microprobe analyses of emeralds, especially for $\mathrm{SiO}_{2}$, which is calculated by difference, combined with the calculation of $\mathrm{H}_{2} \mathrm{O}$ in the mineral structure [10], meaning that we use these data as advisory values only, to filter samples for the trace element geochemical compositions.

Of relevance here is that $\mathrm{BeO}$ in emerald is calculated stoichiometrically from electron microprobe data [1], so an advantage of solution ICP-MS is that it is possible to quantitatively determine Be abundance. Examined emerald compositions fall within the major element compositions of beryls, and within previously identified compositions for emerald types (Figure 3). Type IA emeralds are distinguished from IIB, IID and IC emeralds by lower $\mathrm{V}$ contents relative to $\mathrm{Cr}$ and Fe. Minor elements in emeralds include the chromophores $\mathrm{Cr}$ and V, as well as high Cs $(1$ to $>1000 \times$ continental crust $(C C)), \mathrm{Li}(1$ to $>100 \times \mathrm{CC}), \mathrm{Rb}, \mathrm{Sc}$, $\mathrm{Ga}, \mathrm{Zn}, \mathrm{Pb}, \mathrm{Sr}$ and $\mathrm{Ni}$ (Figure 5). These results are consistent with prior studies of element compatibility in emerald [12,18,25].

\subsection{Trace Element Abundance Composition of Emeralds}

Emeralds are characterized by having elevated large ion lithophile element abundances and low rare earth element (REE) contents with respect to the continental crust $(\mathrm{REE}=0.0001-0.1 \times$ continental crust $(\mathrm{CC}))$, with CC-normalized patterns ranging from flat (IIB, Colombia), light REE-rich (La-Sm; IC, Nigeria), middle to heavy REE-rich (Eu-Yb; IIA, Austria) to flat with heavy REE (Er, Tm, Yb) enrichment (IA, IID) (Figure 4). We chose 
to normalize the emerald compositions to continental crust (CC), and outline the rationale for this in the discussion.

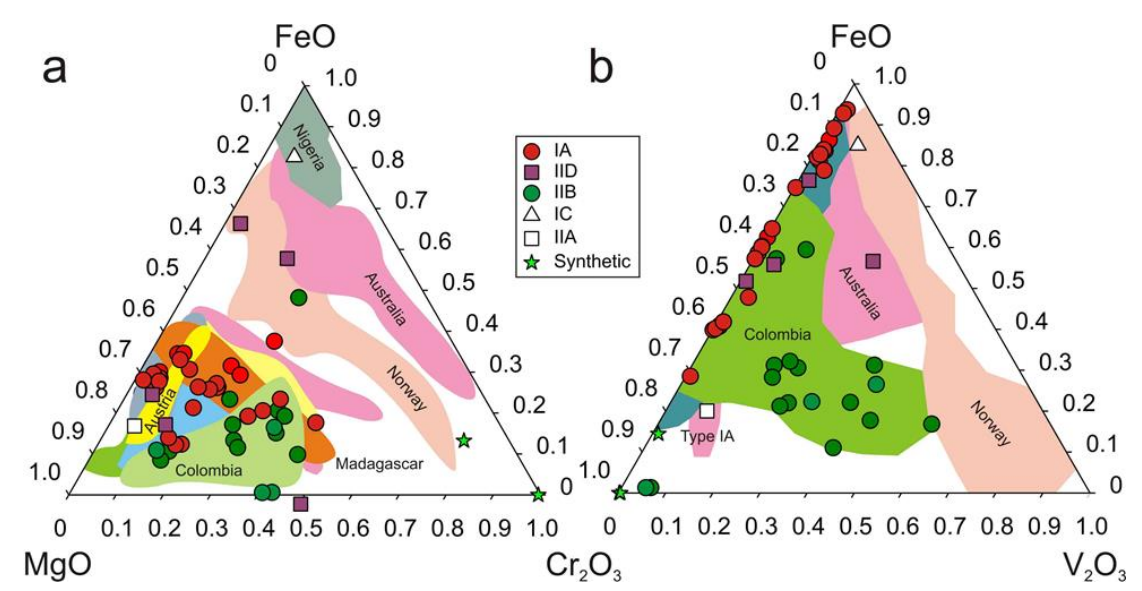

Figure 3. (a) Simplified systematic classification for emeralds (modified after [10]; (b) magnesium$\mathrm{Fe}-\mathrm{Cr}(\mathbf{a})$ and $\mathrm{Cr}-\mathrm{Fe}-\mathrm{V}(\mathbf{b})$ ternary diagrams for global emerald deposits. Data for 'pure emerald' from this study are shown as symbols and published ranges of data are shown as shaded regions. Previously published data sources are given Tables S4 and S5.

Examination of type IA emeralds from global locations (Figure 4a) shows that all share common characteristics of generally low REE and HFSE (Ti, Zr, Ta, Nb, Hf) contents $(\sim<0.1 \times \mathrm{CC})$, positive $\mathrm{W}, \mathrm{Pb}, \mathrm{Zr}$ and Hf anomalies, heavy REE enrichment and upturned patterns for Er, Tm and $\mathrm{Yb}$, with low Er/Lu ratios $(<0.7)$. The HREE enrichments occur in type IA and IID emeralds only, despite these emeralds originating from distinct deposits on different continents. Madagascar (Mananjary deposit), Brazil (Fazenda Farm deposit) and Zambia (Kafubu deposit) emeralds all share these geochemical signatures, irrespective of their distinct deposit geology. The South African emeralds that occur in nearly threebillion-year-old host rocks (Gravelotte deposit; ref. [29]) also have trace element patterns akin to type IA emeralds.

Colombian type IIB emeralds (Figure $4 \mathrm{~b}$ ) are relatively enriched in $\mathrm{Pb}$ and have distinctive nearly flat REE patterns, clearly distinct from type IA emeralds. The incompatible trace element patterns for type IB, IC, IIA, IID and IIC emeralds (Figure 4c) are distinct from one another and from type IA or IIB emeralds. Although the Australian and the North Carolina emerald studied formed in different tectonic environments, their host rocks are sediments, a shared feature with the Colombian emeralds and in agreement with the observed essentially flat CC relative REE patterns. The Nigerian emerald measured is characterized by low incompatible trace element abundances and a light REE-enriched pattern, consistent with formation from its granitic source [30]. The Austrian sample displays a positive concave enrichment trend in the REE compared to CC and with other emeralds.

For the first time, it is possible to provide a generic scheme for ITE abundances in emeralds and show that they have a wide range in absolute and relative abundances, but in general, low REE contents (0.0001-0.1 × CC), with CC-normalized patterns ranging from flat (IIB, Colombia), light REE-rich (La-Sm; IC, Nigeria), middle to heavy REE-rich (Eu-Yb; IIA, Austria) to flat with heavy REE (Er, Tm, Yb) enrichment. This latter group includes all of the type IA emeralds, and an Egyptian type IID emerald deposit.

\subsection{Compositions of Other Beryl Varieties and Inclusion-Rich Emeralds}

Other beryl varieties (Figure 5a) display lower $\mathrm{Pb}$, more variable $\mathrm{U}, \mathrm{Nb}$, Ta, high $\mathrm{Rb}, \mathrm{Cs}$, and Li abundances and generally flat CC-normalized REE patterns. The red beryl sample, hosted in rhyolite, has elevated $\mathrm{Tm}, \mathrm{Yb}$ and $\mathrm{Lu}$ similar to type IA emeralds, although the sense of fractionation is much less extreme, with higher Er/Lu of 1.3 (compared with 0.17-0.7 for type IA emeralds from Mananjary). Trace element and REE patterns of the 
synthetic Gilson emerald from this study are like Colombian emeralds, which might indicate that natural Colombian emerald seeds were used in the process of forming the sample (MGMH\#109678). Two distinct features are the high concentrations of Mo and lack of water, as Gilson synthetic crystals are grown from a lithium molybdate flux [31] and the flux is anhydrous [32]. These two features are widely used in the gem trade as indicators to distinguished natural versus flux grown synthetics; the trace element characteristics of this sample are clear indicators of a synthetic origin.
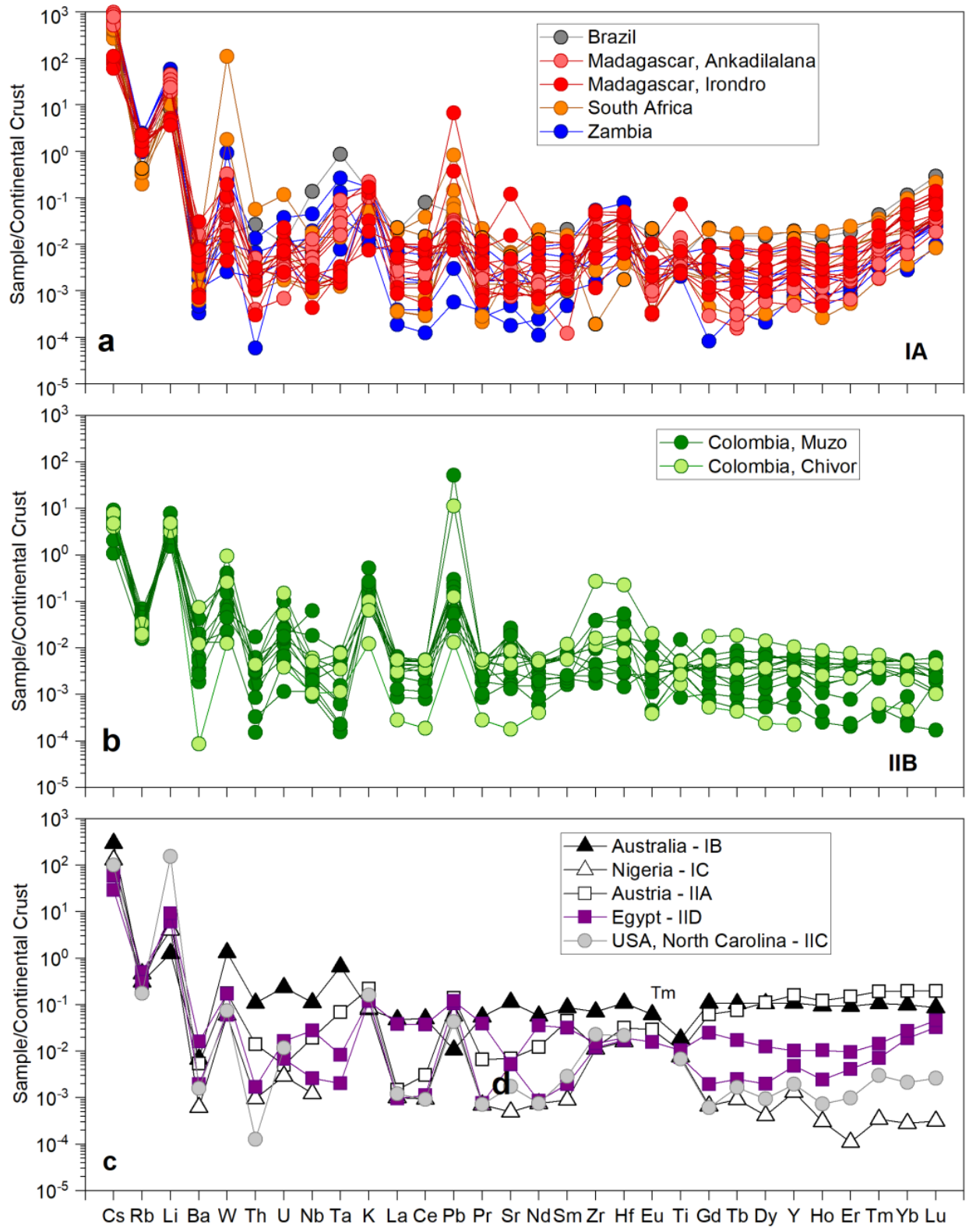

Figure 4. Multi-incompatible trace element (ITE) patterns; (a) ITE patterns for type IA emeralds; (b) ITE patterns for type IIB emeralds; (c) ITE patterns for type IB, IC, IIA, IID and IIC emeralds. Elements are ordered by relative incompatibility and normalized to continental crust composition [28].

In addition to visible evidence for inclusions (Figure $5 b$ ), major element concentrations were measured in the solutions to discriminate the presence of micro/nano inclusions within emerald crystals. It was assumed from the large emerald database that to be considered a 'pure' emerald, $\mathrm{SiO}_{2}$ concentrations range from 55 to $65 \mathrm{wt} . \%, \mathrm{MgO}$ is always less than $3 \mathrm{wt} . \%$ and $\mathrm{BeO}$ ranges from 13 to $16 \mathrm{wt} . \%$ [1]. For this work, any measurement with compositions exceeding these values was considered an impure measurement and 
grouped with the "impure samples" (Figure 5c) discussed here. Secondly, structurally independent minor elements, such as $\mathrm{Ni}, \mathrm{W}, \mathrm{Pb}$ were also used to identify impure analyses. This identification is especially important for Colombian emeralds, which can contain pyrite inclusions that contain these elements. In general, all identified inclusions have much higher Ti concentrations that the host emerald. Most of the inclusions can be distinguished by the high $\mathrm{Ti}, \mathrm{Ge}, \mathrm{Sn}, \mathrm{Ni}$ and $\mathrm{Co}$. Measured inclusions include Colombian pyrite grains with very low REE abundances. These samples (97472 (M) and 12566_incl) are a mixture of sulfides and minor adhering emerald. They are enriched in $\mathrm{Ga}, \mathrm{Zn}, \mathrm{Co}, \mathrm{Pb}$, high $\mathrm{Sn}$ and $\mathrm{U}$, consistent with both being pyrite and have relatively flat CC-normalized REE patterns. These inclusions have no $\mathrm{V}$, a trace element that can be used to identify contaminated samples. An important observation in the case of the inclusions in Type IA emeralds is that they do not have the heavy REE enrichments that are ubiquitously observed in their emerald hosts (Figure 5b).

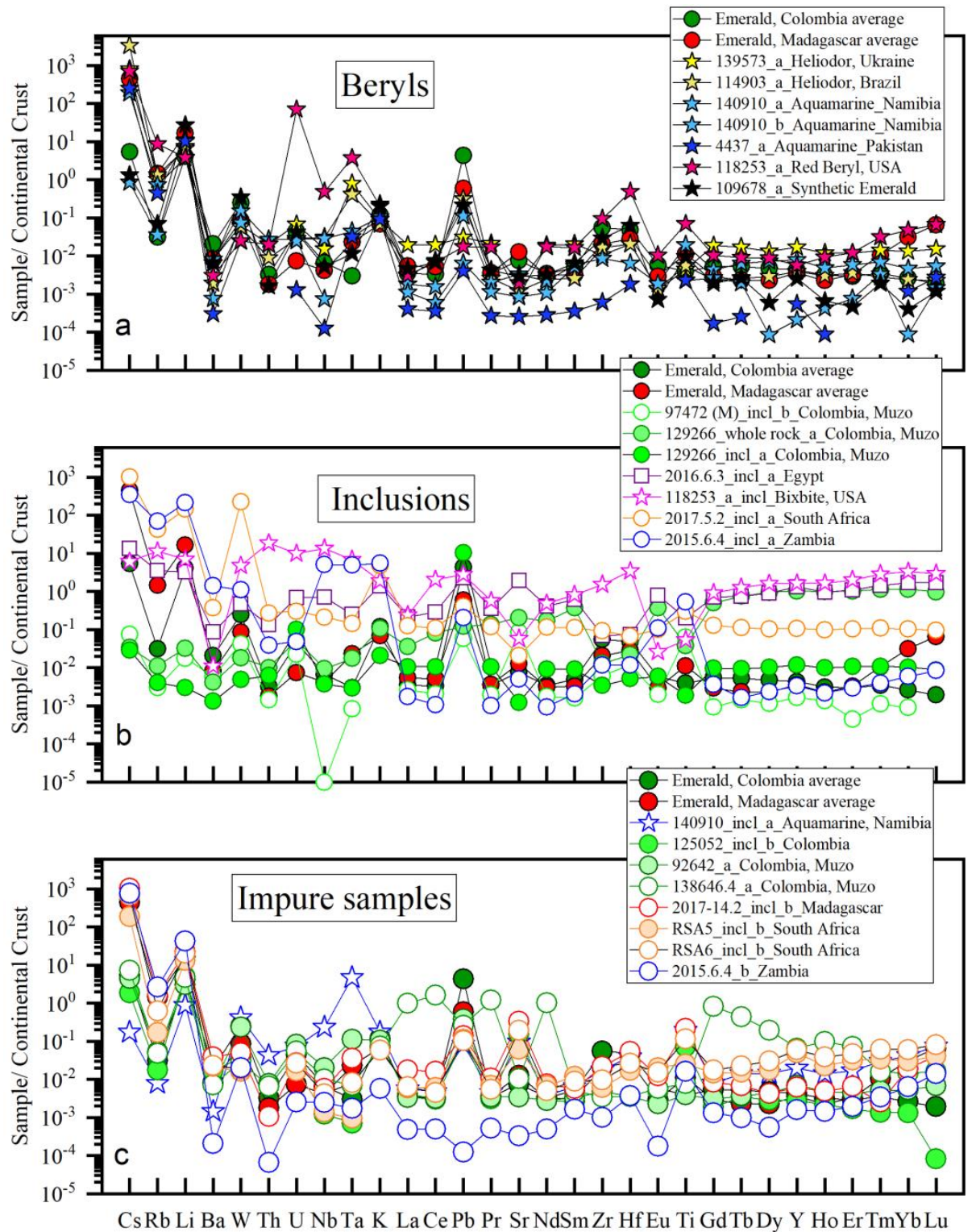

Figure 5. (a) Incompatible trace element pattern for other colored beryls and synthetic emerald; (b) incompatible trace element pattern for pure inclusions and (c) incompatible trace element pattern for impure emeralds (impure samples). Shown for comparison are the pure compositions of type IIB (Colombia) and IA (Malagasy) emeralds. Elements are ordered by relative incompatibility and normalized to continental crust composition [28]. 
It is not always possible to draw conclusions on the type of inclusion measured in the solution ICP-MS data. Nonetheless, all the impure samples (Figure 5c) have high Cs, and $\mathrm{Li}$ as well as Be. Many of the included emeralds also have REE patterns reflective of their respective groups. In some cases, it is possible to identify contaminant type. For example, Sample 138646.4 has high REE abundances, which either reflects parisite or monazite on the outer surface of the emerald. This observation is consistent with the work of [33], who described three emeralds and euclase for REE abundances, which also display relatively flat patterns but at 100 times higher than the concentrations in the emeralds examined here. Similarly, some emeralds appear to have calcite or organic inclusions, such as RSA5 and RSA6, whereas others have mica inclusions (5 June 2016).

\subsection{Trace Element Abundances of Mananjary Deposit Whole-Rocks}

For the Mananjary deposit, Irondro, Madagascar, which is host to type IA emeralds, surrounding country rocks were analyzed, including amphibole-rich 'black wall' and intruding pegmatites. These measurements complement the measurement of emeralds measured from within the black wall host rocks by both solution ICP-MS and LA-ICP-MS (Figure 6, and Tables S2 and S3). The host rocks include high-SiO 2 pegmatite (>75 wt.\%) with low $\mathrm{V}, \mathrm{Cr}$ and Fe contents and the black wall which has lower $\mathrm{SiO}_{2}(\sim 59$ wt.\%), with up to 8.1 wt. $\% \mathrm{FeO}, 1.6 \mathrm{wt} . \% \mathrm{Cr}_{2} \mathrm{O}_{3}$, and up to $100 \mathrm{ppm} \mathrm{V}$. The rocks have elevated CC-like REE abundances relative to the emeralds that they can contain, and relatively flat CC-normalized REE patterns. Measurements of associated emeralds using solution ICP-MS and LA-ICP-MS show elevated concentrations of large ion lithophile elements at $>1 \times$ continental crust $(\mathrm{CC})(\mathrm{e} . \mathrm{g} ., \mathrm{Cs}, \mathrm{Rb})$ and are relatively depleted in high field strength elements (HFSE; Nb, Ta, Ti, Hf, Zr) and the REE at $<0.1 \times \mathrm{CC}$, with notable upturns in the heavy REE (HREE), particularly Tm, Yb and Lu. Local country rocks have distinct incompatible trace element (ITE) patterns, with systematically higher HFSE and REE abundances, and do not show the pronounced upturn in the HREE evident in the emeralds.

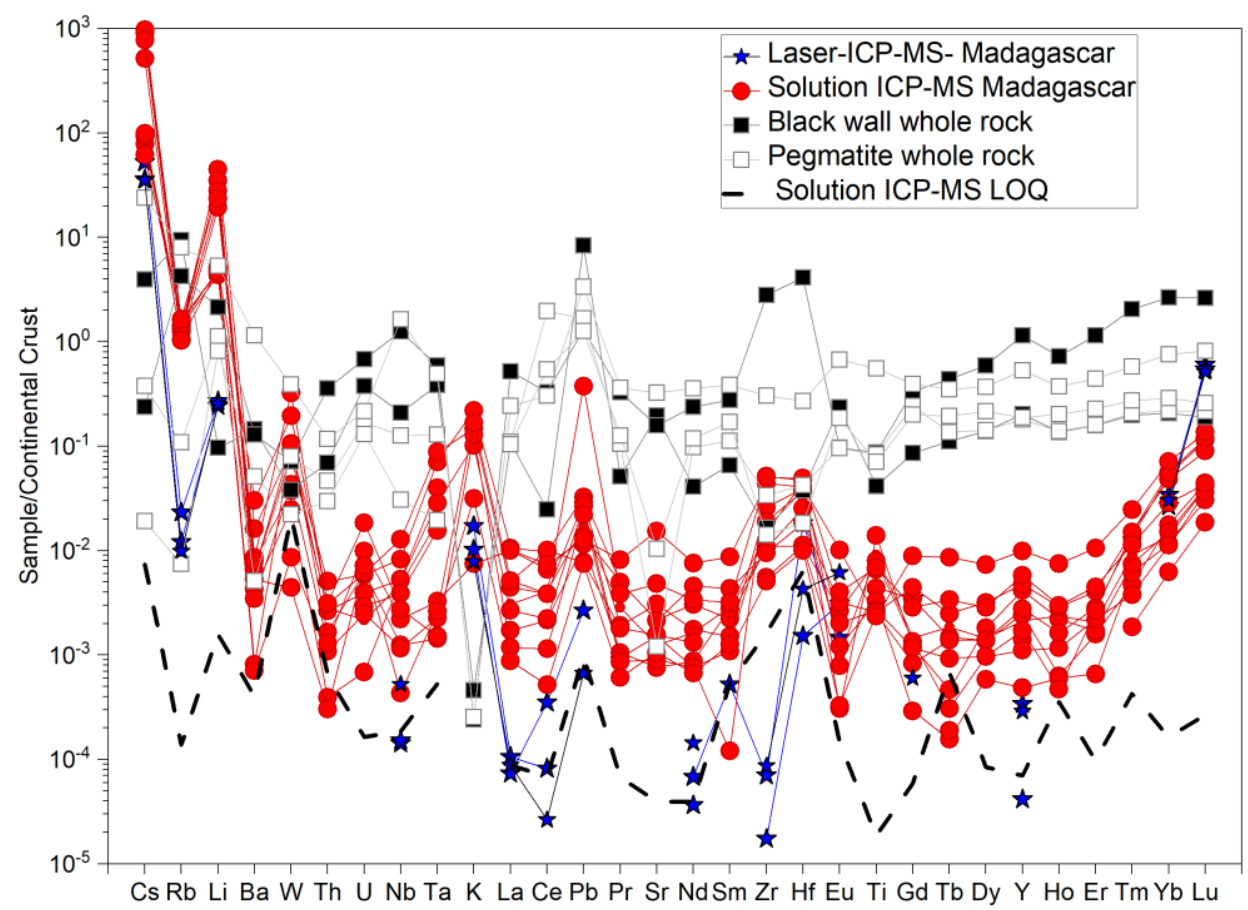

Figure 6. Incompatible trace element pattern for Malagasy emeralds measured by solution ICP-MS and laser ICP-MS; comparison with whole rock analysis of black wall and pegmatites from the same locality and LOQ shown. Elements are ordered by relative incompatibility and normalized to continental crust composition [28]. 


\section{Discussion}

\subsection{Solution Versus Laser-Ablation ICP-MS for Emeralds}

In this study, it was possible to directly dissolve a globally derived suite of emerald fragments for solution ICP-MS analysis. This was practicable due to the availability of a unique collection of gem-quality research emeralds, including cut stones, which in general is not possible as cut stones are both rare and expensive. To provide comparison of datasets from solution ICP-MS and LA-ICP-MS, we measured Malagasy emeralds from the Mananjary deposit using both methods (Figure 6, and SI, Table S3). The direct dissolution of emeralds, versus microbeam techniques such as secondary ionization mass spectrometry (SIMS) or laser ablation ICP-MS, has the advantage of enabling concentrated solutions to be measured, allowing for the accurate and precise determination of trace elements, without crystal-induced matrix effects. As demonstrated here, however, the larger mass of samples can also lead to the issue of the incorporation of inclusions. The advantages of microbeam techniques are that they are minimally destructive, and the careful selection of elements may provide necessary information on the emerald for provenance determination $[5,12,13,18,25,34,35]$, so these methods are likely to proliferate for determining the source locations of individual stones.

To overcome the issue of the incorporation of inclusions in solution ICP-MS analyses of emeralds, a filtering method described above was employed where the major element compositions of the emerald aliquots were compared with a database of $>800$ emerald major element compositions [1]. Analyses with low or high Be contents, anomalous Fe (sulfide inclusions), or $\mathrm{Mg}, \mathrm{Al}, \mathrm{Ca}, \mathrm{K}$ or $\mathrm{Na}$ (silicate inclusions) were rejected from the database of pure emeralds and considered "impure samples" (Figure 5c, and SI, Table S3). These rejections were performed outside of four standard deviation confidence limits. This method is able to distinguish inclusion-bearing emerald aliquots that were measured, but also resulted in the rejection of emerald fragments that did not have visible inclusions, but that were often clouded or opaque. During LA-ICP-MS measurements, no significant variations were observed in trace element abundances that would be consistent with fluid or solid inclusions dominating the incompatible trace element signatures of emeralds, even though such inclusions can occur at the $<100 \mu \mathrm{m}$ scale (Figure 2). Instead, the LA-ICP-MS data support the relative enrichment in the HREE relative to the LREE, as observed in the solution ICP-MS data. The simple rejection criterion we apply to solution ICP-MS data of emeralds therefore has the sensitivity to mark obviously included emeralds as well as those where inclusions may not have been determined from the visual inspection of fragments.

Comparison of the Mananjary emerald compositions determined by solution ICP-MS and LA-ICP-MS shows that the latter method is able to reproduce the overall incompatible trace element pattern measured by the former well for high abundance 'minor' elements. Conversely, this method, along with SIMS analysis, is not able to determine the REE well in most emerald samples, where abundances can be low $(<<1 \mathrm{ppm})$. However, where abundances are sufficient, LA-ICP-MS reproduces the portions of the REE pattern well (Figure 6). For the remainder of this work, we only discuss solution ICP-MS data, acknowledging that LA-ICP-MS will likely proliferate as a method of choice for provenance studies of emeralds $[13,18,25]$, especially in the determination of likely provenance-diagnostic minor elements including $\mathrm{Cs}, \mathrm{Rb}, \mathrm{Li}, \mathrm{Cr}, \mathrm{V}, \mathrm{Sc}, \mathrm{Ga}, \mathrm{Zn}, \mathrm{Ni}, \mathrm{Pb}, \mathrm{Sr}$, and $\mathrm{B}$, within gemquality emerald.

\subsection{Rare Earth Element Distribution in Emeralds and Choice of Continental Crust Normalization}

The REE are highly incompatible and non-essential structural elements in emeralds. The REE are typically trivalent, and so may substitute into the octahedral site, despite their larger ionic radii compared with Al. Alternatively, they may be trapped in the 'water-channels' of the beryl structure [36], exchange with Sc, or occur within fluid and solid inclusions within the emeralds themselves. The REE concentrations in individual emeralds are uniform at the scales of analysis (e.g., solution versus LA-ICP-MS), and are not obviously partitioned into nugget-like inclusions, supporting the bond-length calculations 
that REE are located in the $2 b$ channel water sites in beryl [36]. The REE concentrations are also characteristic for each deposit type, supporting the major distinctions observed between emerald REE compositions and deposit type (Figure 4a-c), a feature that cannot be explained if the REE preferentially partition into emerald.

Another critical question is if the host rocks might impart a distinct geochemical signature to emeralds. Comparison of Malagasy host rocks ('black wall' and pegmatite) incompatible trace element contents with emeralds within the deposit show no REE complementarity (Figure 6). Instead, the Malagasy type IA emeralds are systematically enriched in the heavy REE relative to the whole rocks, suggesting that they inherit their compositions from a different component, and most plausibly, Be-bearing mineralizing fluids. Combined with the evidence for siting in the mineral, the REE are powerful incompatible element tracers of how emeralds form.

In this work, we chose to plot emerald and associated mineral geochemical data versus the estimated composition of continental crust. We did this for several reasons. In general, geochemists typically plot data relative to a large-scale reservoir; either carbonaceous chondrite meteorites, such as Ivuna (CI, sometimes referred to as C1), an estimate of the bulk silicate Earth, otherwise sometimes referred to as primitive mantle (PM), or continental crust (CC). For meteorites and planetary reservoirs, CI makes sense since chondritic starting compositions were likely. For mantle-derived rocks, normalization to PM is logical since this is analogous to the source reservoir. For emeralds, CC is relevant for the same reasons; based on current knowledge, emeralds are exclusively hosted within continental crustal rocks and many are formed from such protoliths [10]. Despite this logic, it is likely that future emerald trace element studies will continue to use CI or PM normalization. The effect of using these normalizations rather than CC will be to change the shape of curves slightly on normalized multi-incompatible trace element plots, but the prominent trends observed in emeralds, especially for the REE, will remain.

\subsection{Trace Element Indicators of Origin for Colombian, Nigerian and Austrian Emeralds}

In the case of type IIB emeralds from Colombia (Figure $4 \mathrm{~b}$ ), all exhibit relatively flat CC-normalized patterns, similar in composition to shales and loess [37]. Colombian emeralds are also characterized by relative enrichments in $\mathrm{Zr}, \mathrm{Hf}$, and $\mathrm{Pb}$ and depletions in $\mathrm{Nb}$ and $\mathrm{Ta}$, relative to $\mathrm{CC}$ composition, reflective of a $\mathrm{Nb}$ - and Ta-depleted subduction component in the sediments. These geochemical signatures are linked with the formation of the emeralds within sedimentary rocks preserved in the Colombian portion of the Andean Cordillera. The Colombian emerald REE compositions therefore demonstrate origination from a shale host rock and sedimentary evaporitic brine fluid, consistent with sedimentary/metamorphic fluid compositions $[15,16]$. The flat CC-normalized REE patterns of the Colombian emeralds reflect the accidental incorporation of associated fluid compositions during emerald mineralization and are unaffected by the late-stage mineralization of other REE-rich minerals in the same assemblage [16].

For type IC emeralds from Nigeria (Figure 4c), the light REE enrichment within them are consistent with generation from late-stage peralkaline granitic fluids from a shallow source, as proposed previously [38]. The type IIA Austrian emerald (Figure 4c) that we examined from the Hachbachtal deposit has a pronounced 'humped' REE pattern with relative light REE depletion relative to the CC composition and is similar to REE patterns exhibited by garnet. This pattern is consistent with the juxtaposition of garnet mica schist and serpentine and subsequent metasomatism of the schist by fluids from the serpentinite [10]. The well-defined deposit models for these type IIB, IC and IIA emeralds demonstrate the utility of using relative and absolute abundances of the REE to examine emerald formation processes. In turn, trace element abundance analyses in emerald represent a powerful new tool for understanding their formation, and we explore this for the enigmatic type IA emeralds. 


\subsection{Modelling the Fluid Compositions and Origins of Type IA Emeralds}

Type IA emeralds are the most geochemically remarkable, yet also the most common type of emeralds found in Earth (Figures 4a and 7a). Their REE patterns are systematically enriched in $\mathrm{Er}, \mathrm{Tm}, \mathrm{Yb}$ and $\mathrm{Lu}$ relative to the other REE, no matter their location globally, host rocks, or formation age, and despite significant differences in more compatible minor and trace elements. These patterns occur in both cut gemstones and raw but pure mineral emerald fragments. The REE signature of these emeralds appears to be diagnostic of their formation environment. To examine the role of fluid composition that led to emerald mineralization, we were initially guided by previous work suggesting the requirement for granitic fluids [10]. Several lines of evidence support this conclusion; data from hydrogen and oxygen isotopes suggest magmatic/metamorphic fluids for type IA emeralds [1,39-41]. Incompatible trace elements, especially $\mathrm{Be}, \mathrm{Cs}$ and $\mathrm{Li}$, as well as high $\mathrm{SiO}_{2}$, implicate evolved magmatic (granite) fluids, with compatible elements distinct from mafic host rocks. Indeed, the association of emerald and felsic continental rocks is well documented [42].

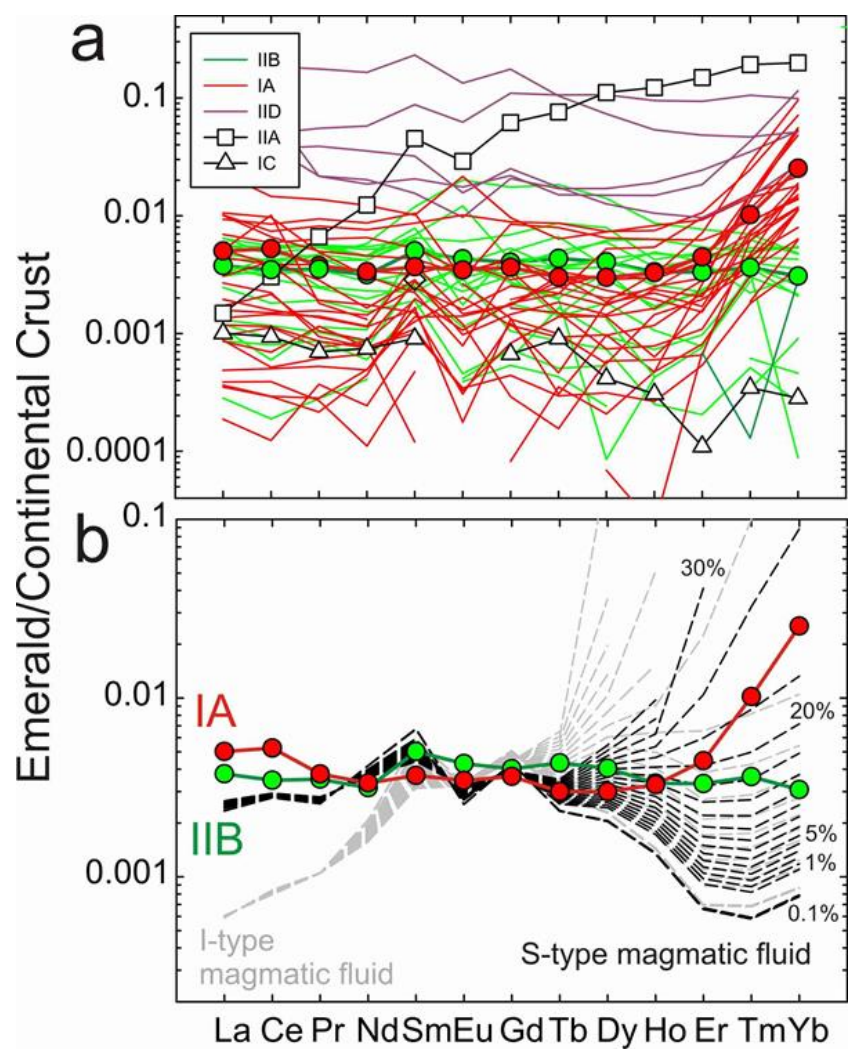

Figure 7. Emerald formation and the REE; (a) rare earth element patterns of major emerald types (IIB, IA IID, IIA, IC); (b) the formation of emeralds from S-type magmatic fluid compositions, rather than I-type granitic fluid compositions. Compositions of magmatic fluids were modelled using initial chemical/modal constituents from [43], and trace-element partitioning from [44,45]. Batch melting followed by fractional crystallization was used to produce resultant melts and fluids. Elements are ordered by relative incompatibility and normalized to continental crust composition [28]. Details of the model are provided in the text.

All major granite types were initially considered, but M-type and A-type granite compositions were rejected due to their mineralogical compositions, which do not lead to significant heavy REE enrichment in fluids after partial melting and fractional crystallization. This is a requirement for fluids responsible for emerald genesis, as M-type granites are generally poor in large ion lithophile elements and A-type are typically anhydrous, with high-Si and low large ion lithophile element concentrations. Instead, focus was placed on S-type granites-the result of regional metamorphic melting of meta-sediments, where 
characteristic minerals are biotite, muscovite, cordierite and garnet-and I-type granites, formed during subduction at continental margins, partially melting deep crustal igneous rocks where characteristic minerals are amphibole and sphene. Given the geological settings of many emeralds at continental sutures, S-type granites are the likely candidates for fluid sources. Assuming a similar system of melting [46] to MnNCKFMASHT and MnNCKFMASHTO (MnO- $\mathrm{Na}_{2} \mathrm{O}-\mathrm{CaO}-\mathrm{K}_{2} \mathrm{O}-\mathrm{FeO}-\mathrm{MgO}-\mathrm{Al}_{2} \mathrm{O}_{3}-\mathrm{SiO}_{2}-\mathrm{H}_{2} \mathrm{O}-\mathrm{TiO}_{2}-\mathrm{Fe}_{2} \mathrm{O}_{3}$ ), it is possible to infer depths of S-type generation in the region of crustal depths between 10 and $25 \mathrm{~km}(\sim 3$ to $8 \mathrm{Kbar})$ and temperatures of between 675 to $725^{\circ} \mathrm{C}$, where garnet, cordierite and sillimanite may all be present at the onset of partial melting.

For the purposes of modelling (Figure 7a,b), we used I- and S-type granite modal abundances of minerals from the classic study of Lachlan fold belt granites [43] (S-Type modal \% (Av, St. Dev) $=35 \pm 8$ quartz, $20 \pm 14$ potassium feldspar; $25 \pm 8$ plagioclase; $3 \pm 2$ muscovite, $15 \pm 8$ biotite; $2 \pm 1$ andalusite; $8 \pm 8$ cordierite; 2 garnet; $0.2 \pm 0.1$ opaque minerals; $0.3 \pm 0.1$ apatite; A-Type modal \% (Av, St. Dev) $=25 \pm 9$ quartz, $15 \pm 14$ potassium feldspar; $41 \pm 11$ plagioclase; 0.2 muscovite, $9.9 \pm 5.3$ biotite; $10 \pm 6.3$ hornblende; 2.2 clinopyroxene; 0.9 opaque minerals; 0.3 sphene; $0.3 \pm 0.2$ apatite). These data were combined with trace-element partitioning data [44,45], or from the GERM database (https: / / earthref.org/GERM/; accessed on 18 June 2019) for these mineral phases. Data modelling used approaches previously outlined [47]. We examined both batch melting and fractional melting processes for the generation of partial melt products. In batch melting, trace elements in the melt and solids are in equilibrium as melting proceeds and until enough melt accumulates so that it can migrate away from the melting zone. In fractional melting, small batches are removed from the melting zone continuously. We employed a batch melting process to mimic the extraction of an S-or I-type melt with reported mineral proportions [48]. We then assumed progressive fractional crystallization of the resulting melts to form evolved magmatic fluids. The extensive fractionation of melts would be required to lead to the high $\mathrm{Cs}$ and $\mathrm{Li}$ of the emeralds, and the models implicate $>35 \%$ fractional crystallization in all cases. Melting and fractional crystallization processes were carried out in $1 \%$ increments.

The modelling constraints imply that type IA emeralds require the involvement of magmatic fluids derived from sedimentary or supercrustal (S-type) granite melts. S-type granites are distinct from other granite types (e.g., igneous (I), anorogenic (A), mantlederived (M)-types) in requiring calc-alkaline or peraluminous sources, being relatively lowtemperature melt products, and being uniquely associated with subduction processes [48]. The requirement of an S-type granite source comes from the need to explain the enrichment in $\mathrm{Er}, \mathrm{Tm}$ and $\mathrm{Yb}$ in type IA emeralds, indicating that both garnet and cordierite were likely to be present in the fluid source. Sensitivity tests assuming typical mineralogy shows that I-type fluids cannot account for IA emerald compositions due to a lack of cordierite (Figure $7 \mathrm{~b}$ ). The results indicate that type IA emerald compositions can be attained via extensive fractional crystallization ( $>35$ to $>60 \%$ ) of S-type partial melts during relatively shallow-level (10-25 km) melting, where such melting is possible. These results also suggest that type IID emeralds, which are considered to form from metamorphic processes acting on mafic-ultramafic precursor lithologies, are in fact likely to have formed from similar protoliths to type IA emeralds (Figure 4c).

\subsection{Wider Implications of the REE Chemistry of Emeralds}

Beryllium is a highly incompatible element, concentrated in the Earth's upper crust by a factor of $\sim 30$ relative to the estimate for the primitive mantle [49]. The occurrence of beryllium-rich minerals is typically associated with felsic magmatic occurrences [42,50]. The modeling of emerald compositions supports the requirement that extensive differentiation is needed to enrich rocks sufficiently in Be for beryllium minerals to form [51]. The comparison of $>120$ Be-bearing minerals [49] showed that diversification in Be mineralogies occurred during distinct time periods at $\sim 2.5,1.8$, and $0.525 \mathrm{Ga}$, corresponding to major collisional phases of the supercontinents Kenorland, Nuna, and Gondwana, respectively and 
at $275 \mathrm{Ma}$ (USA, Russia, Norway) related to the Variscan orogeny. In all cases, the global emerald suite that we have examined has strong association with continental collision and orogens (Figures 8 and 9). The majority of type IA emerald deposits are associated with the Pan-African orogeny and the formation of Gondwanaland, whereas a smaller fraction is also associated with the closure of the Tethys ocean and the Alpine orogeny. This analysis of the trace element compositions of type IA emeralds strongly suggests their formation within collisional tectonic environments.

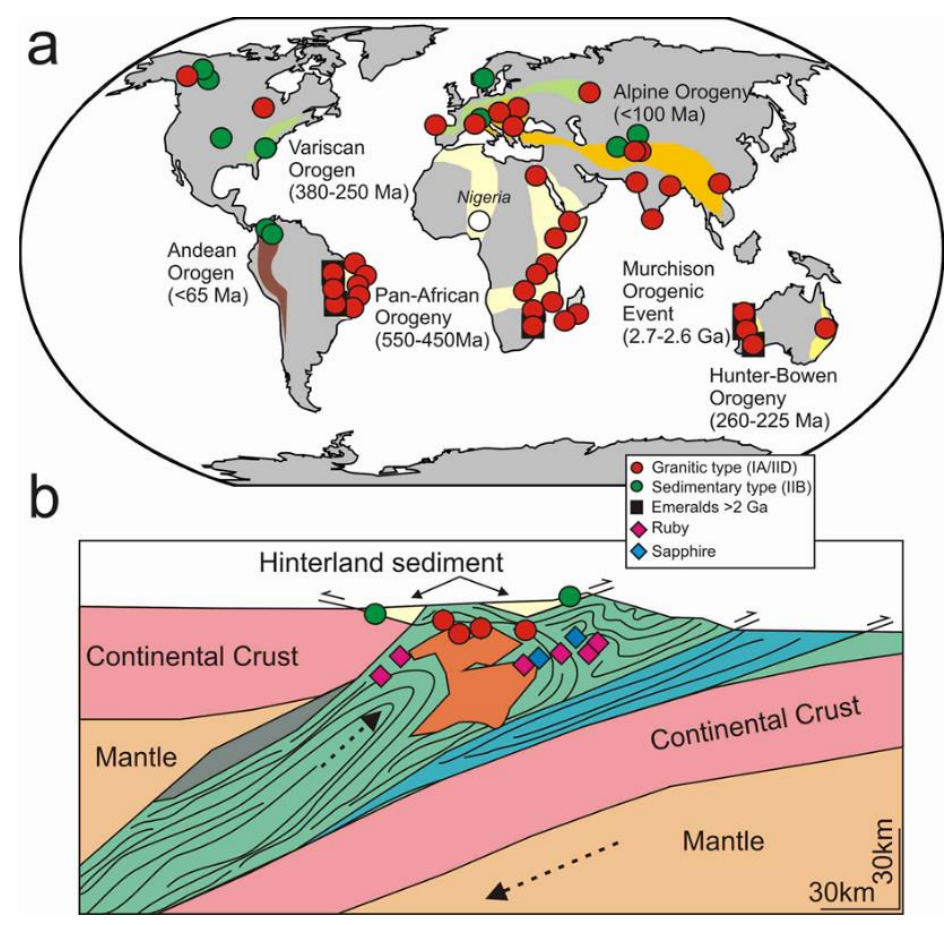

Figure 8. (a) Emerald types associated with major orogenic events in Earth history and; (b) relative distribution of emeralds, rubies and sapphires in continental collision events (modified after [52]). In (a), emerald deposits $>2$ billion years are shown with a black square outline, including the South African samples analyzed here. Orogenic events and rough geographic distribution are shown with colors. In (b), approximate mineralization locations as well as compositions are shown relative to ruby and sapphire formation depths. Rocks in green and blue are metamorphosed sediments and in dark orange are intrusive granitic bodies, with continental crust shown in pink and the mantle in light orange.

The oldest purported emeralds examined in this study come from the Gravelotte deposit, South Africa. The emeralds have been indirectly dated through $\mathrm{U}-\mathrm{Pb}$ chronology of their host rocks at $2.97 \mathrm{Ga}$ [29]. The Gravelotte emeralds have identical REE patterns to type IA emeralds (Figure 4a). Given the diagnostic nature of incompatible trace elements, and the REE, in particular for emeralds, this would suggest a similar formation process for the South African emeralds as for emeralds from Madagascar, Brazil, Zambia and Egypt. At face value, these results would imply that processes of sediment-rich collision and orogeny were occurring in the Archaean to form the Gravelotte emeralds, extending the diversification of Be mineralogies to 3 Ga. Direct dating of Gravelotte emeralds will be important for assessing the implications this result might have for Archaean tectonic processes, along with marginally younger emerald deposits, such as those in Brazil or Australia, which also suggest an ancient heritage $[9,53]$. 


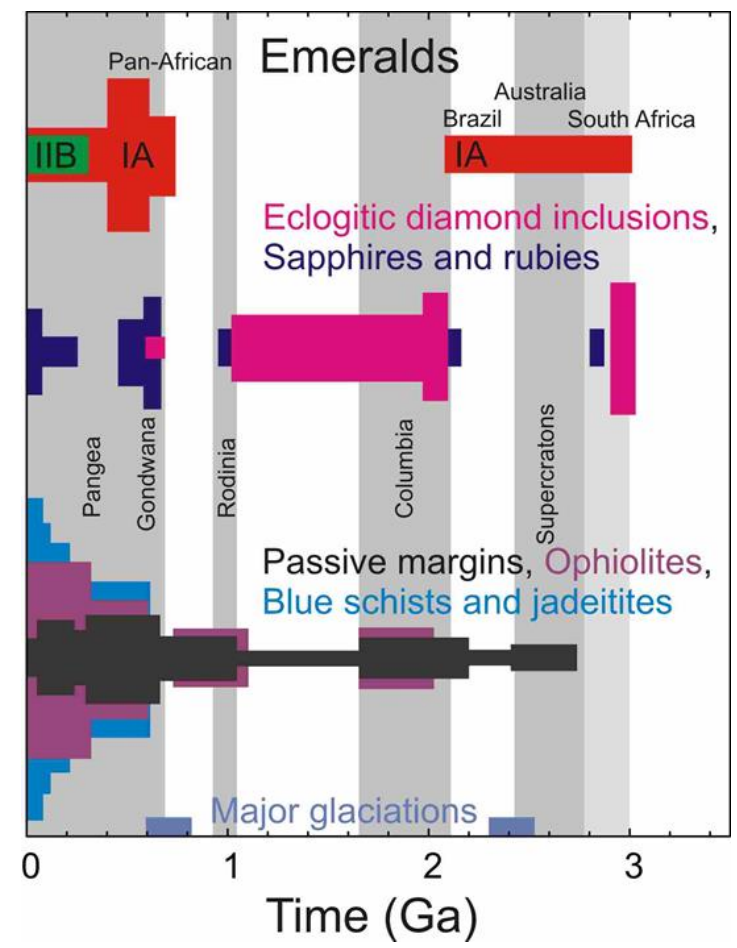

Figure 9. Example of the relations of emeralds and other indicators of plate tectonics with time. Distributions are shown as relative abundances of deposits for emeralds, or as relative distributions from histograms for passive margin distribution [55], eclogitic diamond inclusions [54], and blue schists, lawsonite, jadeitite, ophiolites, sapphires and rubies [52]. Additionally, shown are major supercontinent episodes (Supercratons, Columbia, Rodinia, Gondwana and Pangea) and onset of continent formation, as well as major glaciations [56]. Sedimentary lubrication events following major glaciations have been inferred by the latter study. Emerald age compilation is given in the Supplementary Information.

It has been suggested that diamond, ruby, sapphire and jadeite are archetypal plate tectonic gemstones [52]. Emerald and beryl in general have lower density (specific gravity $=2.6-2.7)$ and are less resilient (7.5-8 Mohs Scale of Hardness) than diamonds or corundum (hardness $>9$, specific gravity $>3.3$ ), so are less likely to be preserved as placer minerals. However, beryl and emerald are reasonably common in continental settings, and have a diagnostic trace element signature within the mineral itself. To date, no other gemstone has been recognized to preserve such information. The reason for the utility of emerald as an indicator mineral of tectonic process lies in its mineral structure, which enables the incorporation of incompatible trace elements. Despite large age gaps that may be partly driven by sampling or rock record preservation, colored gemstones (emerald, ruby, and sapphire) indicate similar distributions of formation between 2 and $3 \mathrm{Ga}$ and $0.6 \mathrm{Ga}$ to the present [52], whereas eclogitic inclusions in diamond are prevalent at $3 \mathrm{Ga}$, and then from 2 to $0.5 \mathrm{Ga}$ (Figure 9). Eclogitic diamond inclusions preserve evidence for deep subduction processes [54], whereas colored gemstones appear to derive from shallower processes during collisional tectonic processes ([52]; this study). These results suggest periodic formation and subsequent preservation of the different gemstones, possibly consistent with varied sensitivity to lithospheric/sub-lithospheric (diamond) and crustal (colored gemstone) tectonic processes.

The formation of the majority of Type IA emeralds occurred at or around the time of the formation of the Pan African Orogenic Belt. This period was preceded by a time where shallow level tectonic processes were seemingly limited (e.g., [56]), and when there was a notable increase in eclogitic diamond inclusion occurrences [54]. The onset of subduction after this time has been attributed to increased 'lubricating' sediment input at subduction 
zones, invigorating the plate tectonic process [56]. Type IA emeralds from the Pan African Orogenic Belt require melting of sediments during continental collision, indicating significant sediment input following subduction. Similar signatures in Archaean emeralds either represent the incorporation of sediments during subduction, or the extensive thickening of sediments within continental crust; in either case, partial melting of sediment is required to drive emerald formation. Identifying emerald as a plate tectonic gemstone through their trace element geochemistry provides predictive power to deposit formation; the incorporation of sediments and shallow melting or metasomatism in orogens, combined with ultramafic protoliths at or close to the surface to provide formation conditions for world-class emerald deposits.

Supplementary Materials: The following are available online at https://www.mdpi.com/article/ 10.3390/min11050513/s1, Table S1: Trace element abundance data (in ppm) for emeralds; Table S2: measurements of standard reference materials for emerald analysis campaigns; Table S3: complete major and trace element data for emeralds, other beryls, inclusions, impure samples and Malagasy host rocks; Table S4: emerald deposit types, ages, environments and host rocks; Table S5: emerald deposit bibliography—references for Tables 1 and S4.

Author Contributions: Both authors provided conceptualization, formal analysis, methodology, investigation, resources, data curation, and writing. All authors have read and agreed to the published version of the manuscript.

Funding: This research received no external funding. Financial support for this work came from Harvard University and Scripps Institution of Oceanography.

Data Availability Statement: The authors declare that data supporting the findings in this study are available within the paper. Samples are available upon request from the Mineralogical and Geological Museum, Harvard University (MGMH).

Acknowledgments: We are grateful to A. Hart, H.A. Hänni, J. Ferry, P. Lyckberg, S. Pouroulis, H. Zwaan, M. Southwood and Gemfields for their generous provision of samples, in addition to the MGMH samples. R. Hattingh is thanked for assistance with data collection. G. Angarita, A. Palke and G. Pearson are acknowledged for discussions and encouragement during various stages of this project. Comments by G. Harlow, E. Grew, G. Franz, H. Zwaan and numerous anonymous reviewers on four previous versions of this manuscript are acknowledged. We dedicate this work to Artemis and Salome Pouroulis, who provided great insight to the Gravelotte emerald deposit.

Conflicts of Interest: The authors declare no conflict of interest. Correspondence and requests for materials should be addressed to R.A.P. (ralonso@fas.harvard.edu).

\section{References}

1. Groat, L.A.; Giuliani, G.; Marshall, D.D.; Turner, D. Emerald deposits and occurrences: A review. Ore Geol. Rev. 2008, 34, 87-112. [CrossRef]

2. Schwarz, D.; Schmetzer, K.T. The definition of emerald. Extralapis 2002, 2, 74-78.

3. Giuliani, G. La spirale du temps de l'émeraude. Règne Minéral 2011, 98, 31-41.

4. Grundmann, G.; Morteani, G. Emerald Mineralization during Regional Metamorphism-The Habachtal (Austria) and Leydsdorp (Transvaal, South-Africa) Deposits. Econ. Geol. 1989, 84, 1835-1849. [CrossRef]

5. Zwaan, J.C. Gemmology, geology and origin of the Sandawana emerald deposits, Zimbabwe. Scripta Geol. 2006, 131, 1-212.

6. Andrianjakavah, P.R.; Salvi, S.; Béziat, D.; Rakotondrazafy, M.; Giuliani, G. Proximal and distal styles of pegmatite-related metasomatic emerald mineralization at Ianapera, southern Madagascar. Miner. Depos. 2009, 44, 817-835. [CrossRef]

7. Loughrey, L.; Marshall, D.; Ihlen, P.; Jones, P. Boiling as a mechanism for colour zonations observed at the Byrud emerald deposit, Eidsvoll, Norway: Fluid inclusion, stable isotope and Ar-Ar studies. Geofluids 2013, 13, 542-558. [CrossRef]

8. Groat, L.A.; Turner, D.J.; Evans, R.J. 13.23-Gem Deposits. In Treatise on Geochemistry, 2nd ed.; Holland, H.D., Ed.; Elsevier: Amsterdam, The Netherlands, 2014; Volume 13, pp. 595-622. [CrossRef]

9. Marshall, D.; Downes, P.; Ellis, S.; Greene, R.; Loughrey, L.; Jones, P. Pressure-Temperature-Fluid Constraints for the Poona Emerald Deposits, Western Australia: Fluid Inclusion and Stable Isotope Studies. Minerals 2016, 6, 130. [CrossRef]

10. Giuliani, G.; Groat, L.A.; Marshall, D.; Fallick, A.E.; Branquet, Y. Emerald Deposits: A Review and Enhanced Classification. Minerals 2019, 9, 105. [CrossRef] 
11. Franz, G.; Vyshnevskyi, O.; Taran, M.; Khomenko, V.; Wiedenbeck, M.; Schiperski, F.; Nissen, J. A new emerald occurrence from Kruta Balka, Western Peri-Azovian region, Ukraine: Implications for understanding the crystal chemistry of emerald. Am. Mineral. J. Earth Planet. Mater. 2020, 105, 162-181. [CrossRef]

12. Aurisicchio, C.; Conte, A.M.; Medeghini, L.; Ottolini, L.; De Vito, C. Major and trace element geochemistry of emerald from several deposits: Implications for genetic models and classification schemes. Ore Geol. Rev. 2018, 94, 351-366. [CrossRef]

13. Saeseaw, S.; Renfro, N.D.; Palke, A.C.; Sun, Z.; McClure, S.F. Geographic Origin determination of emeralds. Gems Gemol. 2019, 55, 614-646. [CrossRef]

14. Branquet, Y.; Laumonier, B.; Cheilletz, A.; Giuliani, G. Emeralds in the Eastern Cordillera of Colombia: Two tectonic settings for one mineralization. Geology 1999, 27, 597-600. [CrossRef]

15. Ottaway, T.; Wicks, F.; Bryndzia, L.; Kyser, T.; Spooner, E. Formation of the Muzo hydrothermal emerald deposit in Colombia. Nature 1994, 369, 552. [CrossRef]

16. Giuliani, G.; France-Lanord, C.; Cheilletz, A.; Coget, P.; Branquet, Y.; Laumomnier, B. Sulfate reduction by organic matter in Colombian emerald deposits: Chemical and stable isotope (C, O, H) evidence. Econ. Geol. 2000, 95, 1129-1153. [CrossRef]

17. Cooper, M.; Addison, F.; Alvarez, R.; Coral, M.; Graham, R.H.; Hayward, A.; Howe, S.; Martinez, J.; Naar, J.; Peñas, R. Basin development and tectonic history of the Llanos Basin, Eastern Cordillera, and middle Magdalena Valley, Colombia. AAPG Bull. 1995, 79, 1421-1442.

18. Karampelas, S.; Al-Shaybani, B.; Mohamed, F.; Sangsawong, S.; Al-Alawi, A. Emeralds from the most important occurrences: Chemical and spectroscopic data. Minerals 2019, 9, 561. [CrossRef]

19. Fritsch, E.; Rossman, G.R. An update on color in gems. Part 2: Colors involving multiple atoms and color centers. Gems Gemol. 1988, 24, 3-15. [CrossRef]

20. Turner, D.; Groat, L.A.; Hart, C.J.; Mortensen, J.K.; Linnen, R.L.; Giuliani, G.; Wengzynowski, W. Mineralogical and geochemical study of the True Blue aquamarine showing, southern Yukon. Can. Mineral. 2007, 45, 203-227. [CrossRef]

21. Nassau, K.; Wood, D. An examination of red beryl from Utah. Am. Mineral. J. Earth Planet. Mater. 1968, 53, 801-806.

22. Falster, A.U.; Simmons, W.B.; Webber, K.L.; Boudreaux, A.P. Mineralogy and Geochemistry of the Erongo Sub-Volcanic GraniteMiarolitic-Pegmatite Complex, Erongo, NamibiaMiarolitic Pegmatites, Erongo. Can. Mineral. 2018, 56, 425-449. [CrossRef]

23. Agheem, M.H.; Shah, M.T.; Khan, T.; Laghari, A.; Dars, H. Field features and petrography used as indicators for the classification of Shigar valley pegmatites, Gilgit-Baltistan region of Pakistan. Himal J. Earth Sci. Univ. Peshawar. 2011, 44, 1-7.

24. Nassau, K. Synthetic emerald: The confusing history and the current technologies. J. Cryst. Growth 1976, 35, 211-222. [CrossRef]

25. Hattingh, R.; Alonso-Perez, R.; Palke, A.C.; Groat, L.; Day, J.M.D. Comparison of Laser Ablation and Solution ICP-MS Analyses of Emeralds. Gems Gemol. 2018, 55, 297.

26. Day, J.; Peters, B.J.; Janney, P.E. Oxygen isotope systematics of South African olivine melilitites and implications for HIMU mantle reservoirs. Lithos 2014, 202, 76-84. [CrossRef]

27. Tait, K.T.; Day, J.M.D. Chondritic late accretion to Mars and the nature of shergottite reservoirs. Earth Planet. Sci. Lett. 2018, 494, 99-108. [CrossRef]

28. Rudnick, R.L.; Gao, S. Composition of the continental crust. Treatise Geochem. 2003, 3, 659.

29. Poujol, M. U-Pb isotopic evidence for episodic granitoid emplacement in the Murchison greenstone belt, South Africa. J. Afr. Earth Sci. 2001, 33, 155-163. [CrossRef]

30. Schwarz, D.; Kanis, J.; Kinnaird, J. Emerald and green beryl from Central Nigeria. J. Gemol. Lond. 1996, 25, 117-141. [CrossRef]

31. Schmetzer, K.; Gilg, H.A.; Vaupel, E. Synthetic Emeralds Grown by W. Zerfass: Historical Account, Growth Technology and Properties. J. Gemmol. 2017, 35, 120-125. [CrossRef]

32. Bersani, D.; Azzi, G.; Lambruschi, E.; Barone, G.; Mazzoleni, P.; Raneri, S.; Longobardo, U.; Lottici, P.P. Characterization of emeralds by micro-Raman spectroscopy. J. Raman Spectrosc. 2014, 45, 1293-1300. [CrossRef]

33. Pignatelli, I.; Giuliani, G.; Morlot, C.; Rouer, O.; Claiser, N.; Chatagnier, P.-Y.; Goubert, D. Recent Advances in Understanding the Similarities and Differences of Colombian Euclases. Can. Mineral. 2017, 55, 799-820. [CrossRef]

34. Zwaan, J.C.; Jacob, D.E.; Häger, T.; Neto, M.T.O. Emeralds from the Fazenda Bonfim Region, Rio Grande do Norte, Brazil. Gems Gemol. 2012. [CrossRef]

35. Saeseaw, S.; Pardieu, V.; Sangsawong, S. Three-phase inclusions in emerald and their impact on origin determination. Gems Gemol. 2014, 50, 114-132. [CrossRef]

36. Bačík, P.; Fridrichová, J. The Site Occupancy Assessment in Beryl Based on Bond-Length Constraints. Minerals 2019, 9, 641. [CrossRef]

37. McLennan, S.M. Relationships between the trace element composition of sedimentary rocks and upper continental crust. Geochem. Geophys. Geosyst. 2001, 2. [CrossRef]

38. Kinnaird, J. Hydrothermal alteration and mineralization of the alkaline anorogenic ring complexes of Nigeria. J. Afr. Earth Sci. 1985, 3, 229-251. [CrossRef]

39. Giuliani, G.; France-Lanord, C.; Zimmermann, J.; Cheilletz, A.; Arboleda, C.; Charoy, B.; Coget, P.; Fontan, F.; Giard, D. Fluid composition, $\delta \mathrm{D}$ of channel $\mathrm{H}_{2} \mathrm{O}$, and $\delta^{18} \mathrm{O}$ of lattice oxygen in beryls: Genetic implications for Brazilian, Colombian, and Afghanistani emerald deposits. Int. Geol. Rev. 1997, 39, 400-424. [CrossRef] 
40. Giuliani, G.; France-Lanord, C.; Coget, P.; Schwarz, D.; Cheilletz, A.; Branquet, Y.; Giard, D.; Martin-Izard, A.; Alexandrov, P.; Piat, D. Oxygen isotope systematics of emerald: Relevance for its origin and geological significance. Miner. Depos. 1998, 33, 513-519. [CrossRef]

41. Marshall, D.; Meisser, N.; Ellis, S.; Jones, P.; Bussy, F.; Mumenthaler, T. Formational Conditions for the Binntal Emerald Occurrence, Valais, Switzerland: Fluid Inclusion, Chemical Composition, and Stable Isotope Studies. Can. Mineral. 2017, 55, 725-741. [CrossRef]

42. Dill, H.G. The "chessboard" classification scheme of mineral deposits: Mineralogy and geology from aluminum to zirconium. Earth-Sci. Rev. 2010, 100, 1-420. [CrossRef]

43. Chappell, B.; White, A. I-and S-type granites in the Lachlan Fold Belt. Earth Environ. Sci. Trans. R. Soc. Edinb. 1992, 83, 1-26.

44. Adam, J.; Green, T. Trace element partitioning between mica-and amphibole-bearing garnet lherzolite and hydrous basanitic melt: 1. Experimental results and the investigation of controls on partitioning behaviour. Contrib. Mineral. Petrol. 2006, $152,1-17$. [CrossRef]

45. Bea, F.; Pereira, M.; Stroh, A. Mineral/leucosome trace-element partitioning in a peraluminous migmatite (a laser ablation-ICP-MS study). Chem. Geol. 1994, 117, 291-312. [CrossRef]

46. Clemens, J.; Buick, I.; Kisters, A. The Donkerhuk batholith, Namibia: A giant S-type granite emplaced in the mid crust, in a fore-arc setting. J. Geol. Soc. Lond. 2017, 174, 157-169. [CrossRef]

47. Hanson, G.N. Rare earth elements in petrogenetic studies of igneous systems. Annu. Rev. Earth Planet. Sci. 1980, 8, 371-406. [CrossRef]

48. Chappell, B.W.; White, A.J. Two contrasting granite types: 25 years later. Aust. J. Earth Sci. 2001, 48, 489-499. [CrossRef]

49. Grew, E.S.; Hazen, R.M. Beryllium mineral evolution. Am. Mineral. 2014, 99, 999-1021. [CrossRef]

50. Dill, H.G. Pegmatites and aplites: Their genetic and applied ore geology. Ore Geol. Rev. 2015, 69, 417-561. [CrossRef]

51. Evensen, J.M.; London, D. Experimental silicate mineral/melt partition coefficients for beryllium and the crustal be cycle from migmatite to pegmatite. Geochim. Cosmochim. Acta 2002, 66, 2239-2265. [CrossRef]

52. Stern, R.J.; Tsujimori, T.; Harlow, G.; Groat, L.A. Plate tectonic gemstones. Geology 2013, 41, 723-726. [CrossRef]

53. Morteani, G. The multi-fluid metasomatic genesis of the Archean Poona emerald deposit (Murchison Province, Western Australia): Microtextures, geochemistry and oxygen isotope composition. Period. Mineral. 2017, 86, 279-300.

54. Shirey, S.B.; Richardson, S.H. Start of the Wilson cycle at 3 Ga shown by diamonds from subcontinental mantle. Science 2011, 333, 434-436. [CrossRef] [PubMed]

55. Bradley, D.C. Passive margins through earth history. Earth Sci. Rev. 2008, 91, 1-26. [CrossRef]

56. Sobolev, S.V.; Brown, M. Surface erosion events controlled the evolution of plate tectonics on Earth. Nature 2019, 570, 52. [CrossRef] [PubMed] 